\title{
PENGARUH BEBAN KERJA TERHADAP KINERJA PERANGKAT NAGARI DALAM PENGELOLAAN KEUANGAN NAGARI DI KABUPATEN TANAH DATAR
}

\author{
Ledita Anastasya \\ Jurusan Administrasi Publik, Fakultas Ilmu Sosial, Universitas Negeri Padang \\ ledithaanastasya@gmail.com
}

\begin{abstract}
This study aims to determine whether the workload influential on the performance of nagari government apparatus in nagari financial management in Tanah Datar Regency. The background of this study was carried out because of the excessive workload received by the nagari government apparatus in nagari financial management in Tanah Datar Regency. This study uses a quantitative methods with population of this study was all nagari government apparatus, which numbered 600 people. Sample in this study was consisted of 248 nagari government apparatus determined with Slovin formula. Besides, sample in this study was determined through Multistage Random Sampling technique. The data was collected through questionnaires using Likert scale measurement. The data was analyzed with multiple linear regression tests. The results of this study showed that the workload variable (simultaneously) influenced the performance of nagari government apparatus in financial management in Tanah Datar Regency. This it could be concluded that workload had a significant effect on the performance of nagari government apparatus in nagari finance management in Tanah Datar Regency.
\end{abstract}

Keywords: Workload, job performance, nagari financial management

How to Cite: Ledita Anastasya. 2019. Pengaruh Beban Kerja terhadap Kinerja Perangkat Nagari dalam Pengelolaan Keuangan Nagari di Kabupaten Tanah Datar. 3(2): pp. 45-56. DOI: https://doi.org/10.24036/jess/vol3-iss2

\section{Pendahuluan}

Otonomi daerah telah memberikan kesempatan yang besar bagi pemerintah daerah dalam melaksanakan keuangan daerahnya agar lebih baik sehingga pemerintah daerah harus mengelola sendiri keuangan daerahnya. Dalam Peraturan Pemerintah Nomor 58 Tahun 2005 tentang Pengelolaan Keuangan Daerah dijelaskan bahwa pengelolaan keuangan daerah merupakan seluruh kegiatan yang meliputi perencanaan, pelaksanaan, penatausahaan, pelaporan, pertanggungjawaban dan pengawasan keuangan daerah.

Dalam Peraturan Pemerintah Nomor 47 Tahun 2015 tentang Peraturan Pelaksanaan Undang-undang Nomor 6 Tahun 2014 tentang Desa, desa diberikan kewenangan mengatur dan mengurus sendiri urusan pemerintahan, dan kepentingan masyarakat yang dibiayai oleh anggaran pendapatan dan belanja desa yang selanjutnya perolehan bagian keuangan desa ini disebut Alokasi Dana Desa 
(ADD). Adapun pembagian anggaran dana desa ini adalah $30 \%$ untuk belanja aparatur dan operasional pemerintah desa dan $70 \%$ untuk pemberdayaan masyarakat desa.

Selanjutnya, dalam Permendagri Republik Indonesia Nomor 20 Tahun 2018 tentang Pengelolaan Keuangan Desa ketentuan umum pasal 1 Ayat 6, keuangan desa diselenggarakan berdasarkan asas-asas transparan, akuntabel, partisipatif dan dilakukan secara tertib dan disiplin anggaran. Pengelolaan keuangan desa ini diselenggarakan selama masa 1 (satu) tahun anggaran yang dimulai tanggal dari 1 Januari sampai dengan tanggal 31 Desember.

Berdasarkan Peraturan Bupati Tanah Datar Nomor 7 Tahun 2016 tentang Perubahan Atas Peraturan Bupati Nomor 11 Tahun 2015 tentang Pedoman Pengelolaan Keuangan Nagari. Peraturan ini memuat tentang bagaimana pengelolaan keuangan nagari di Kabupaten Tanah Datar. Akan tetapi, di Kabupaten Tanah Datar masih banyak ditemukan permasalahan yang terkait dengan pengelolaan keuangan nagari, diantaranya terdapat 3 nagari dari 75 nagari yang tidak dapat mencairkan Anggaran Dana Desa 9 (ADD) Tahap 1. Sehingga mengakibatkan 72 nagari lainnya terkendala dalam pencairan ADD Tahap II yang bersumber dari APBN (sumber berita dari RedaksiSumbar.com, 2017 di akses pada tanggal 20 Mei 2018). Selain itu, permasalahan lain dalam pengelolaan keuangan nagari juga dikemukakan oleh Syamsir dan Rahmi Suci (2018) yaitu di Nagari Tabek Patah adanya ketidaksesuian antara aturan yang dikeluarkan oleh pemerintah pusat dengan aturan yang dikeluarkan oleh pemerintah daerah. Menurut Kaur Pemerintahan jika terdapat sisa dana, pemerintah pusat memperbolehkan menggunakan dana dalam bidang pembangunan yang sama, namun pemerintah daerah tidak memperbolehkan sisa dana dan memasukan dana tersebut ke dalam Sisa Lebih Perhitungan Anggaran (SiLPA) dalam penggunaan ADN. Syamsir dan Nur Putri Jayanti (2018) juga mengemukakan bahwa belum adanya transparansi dalam pengelolaan keuangan nagari di Nagari Pitalah Kecamatan Batipuh, dimana sekretaris nagari jarang melaporkan kondisi keuangan kepada perangkat nagari lainnya. Kemudian di Nagari Tanjung Bungo Kecamatan Batipuh adanya perubahan sistem dalam pengelolaan keuangan nagari.

Selain itu juga berdasarkan hasil wawancara dengan perangkat nagari pada tanggal 30 Mei 2018, ditemukan bahwa adanya keterlambatan dalam penyusunan APBNagari, sehingga perangkat nagari sering lembur pada akhir tahun yang mengakibatkan bertambahnya beban kerja perangkat nagari. Adapun permasalahan perangkat nagari yang terkait dengan beban kerja adalah berdasarkan hasil wawancara yang telah dilakukan pada tanggal 30 Mei 2018 adalah adanya perangkat nagari yaitu Kepala Urusan Simawang yang juga merangkap sebagai Kepala Jorong di nagarinya, yang ini merupakan salah satu indikator dari beban kerja yaitu kemenduaan peran. Selain itu di nagari Padang Magek terdapat perangkat nagari yaitu bendahara nagari, sekretaris serta kepala urusan keuangan sering lembur pada akhir tahun dalam membuat laporan keuangan. Senada dengan itu, walinagari Simawang juga menjelaskan pada akhir tahun perangkat nagarinya juga sering lembur karena ada beberapa pekerjaan yang menumpuk, yang biasanya pada bagian perlengkapan. Dan juga keterlambatan dalam penyusunan APBNagari karena laporan tentang APBNagari 
yang seharusnya disampaikan pada bulan Januari, sedangkan peraturan bupati tentang perubahan APBNagari sampai di walinagari pada bulan Maret.

Berdasarkan penelitian terdahulu yang penulis temukan terdapat hasil penelitian bahwa beban kerja memiliki pengaruh secara signifikan terhadap kinerja yang dilakukan oleh Widyiastuti (2015) dengan judul penelitian Pengaruh Stress Kerja dan Beban Kerja terhadap Kinerja SKPD Kabupaten Sintang Kalimantan Barat. Namun ada juga penelitian yang menyatakan beban kerja tidak memiliki pengaruh signifikan terhadap kinerja, seperti penelitian dari Iskandar (2017) yang berjudul penelitian Pengaruh Karakteristik Individu, Beban Kerja dan Lingkungan Kerja terhadap Kinerja Pegawai pada Karyawan Inspektorat Daerah Provinsi Sulawesi Tengah dengan hasil penelitian beban kerja memiliki pengaruh negatif dan signifikan terhadap kinerja pegawai pada Inspektorat Daerah Provinsi Sulawesi Tengah.

Berlandaskan pada latar belakang masalah di atas, maka penulis telah melakukan penelitian di Kabupaten Tanah Datar tentang Pengaruh Beban Kerja terhadap Kinerja Perangkat Nagari dalam Pengelolaan Keuangan Nagari di Kabupaten Tanah Datar. Penelitian ini adalah intisari dari hasil penelitian skripsi yang merupakan bagian dari penelitian payung yang dilakukan oleh Syamsir (2017) dengan judul Model Pembinaan Aparatur Pemerintah Nagari dalam Pengelolaan Keuangan Nagari di Kabupaten Tanah Datar. Mengenai penelitian ini, maka rumusan masalahnya adalah "Apakah terdapat Pengaruh Beban Kerja terhadap Kinerja Perangkat Nagari dalam Pengelolaan Keuangan Nagari di Kabupaten Tanah Datar?".

\section{Tinjauan Kepustakaan}

\section{Kinerja dan Beban Kerja}

Wirawan (2009), menjelaskan bahwa kinerja singkatan dari kinetika energi kinerja yang dalam bahasa inggris sama dengan performance. Sedangkan Fahmi (2016), menjelaskan kinerja merupakan hasil perolehan suatu organisasi baik yang profit oriented maupun non profit oriented. Kemudian Robbins (dalam Syamsir dan Baiyulis: 2018) menjelaskan kinerja adalah hasil perbandingan antara pekerjaan yang dilakukan oleh karyawan dengan ketentuan yang telah ditentukan oleh organisasi tersebut. Selain itu Sinambela (2017) juga mendefenisikan kinerja merupakan pelaksanaan suatu tugas hingga tugas yang dilakukan sesuai dengan yang diharapkan.

Wirawan (2009) menjelaskan bahwa kinerja dipengaruhi oleh beberapa faktor, yaitu faktor dari dalam diri pegawai, dari dalam organisasi, lingkungan luar organisasi dan budaya masyarakat. Sedangkan menurut Kasmir (2016) menjelaskan bahwa faktor-faktor yang mempengaruhi kinerja adalah kemampuan, pengetahuan, desain kerja, tingkah laku, motivasi, kepemimpinan, gaya kepemimpinan, budaya organisasi, kepuasan kerja, lingkungan kerja, loyalitas, komitmen, dan disiplin kerja. Selain itu Luthan dalam Kasmir, (2016) menjelaskan kinerja tidak saja dipengaruhi oleh usaha, akan tetapi juga dipengaruhi oleh kemampuan, seperti pengetahuan, pekerjaan, keahlian dan bagaimana orang tersebut merasakan beban kerja yang diembannya. 
Menurut Permendagri Nomor 12 Tahun 2008, beban kerja merupakan sejumlah pekerjaan yang diterima oleh organisasi dan merupakan hasil dari volume kerja dan norma waktu. Munandar (2001) menjelaskan bahwa beban kerja merupakan suatu pekerjaan dengan rincian tugasnya yang harus selesai dalam batas waktu tertentu. Selain itu Mangkuprawira (2003) menjelaskan beban kerja seseorang telah ditetapkan dalam bentuk standar kerja perusahaan berdasarkan jenis pekerjaannya. Schultz dan Schultz (dalam Suwatno dan Donni Juni Priansa (2011) juga menjelaskan beban kerja bukan hanya berkaitan dengan kelebihan pekerjaan (work overload), tetapi juga sama atau sebaliknya terlalu rendah/kecil pekerjaan (work underload). Selanjutnya Munandar (2001), mengelompokkan beban kerja kedalam faktor-faktor dari dalam pekerjaan, yaitu tuntutan fisik, dimana kondisi dari pekerjaan tertentu dapat memberikan hasil seperti prestasi kerja yang optimal selain akibatnya terhadap kinerja pegawai, kondisi fisik juga berpengaruh terhadap kondisi mental dan psikologi dari seorang tenaga kerja. Selanjutnya yaitu tuntutan tugas, yaitu sering lembur yang mengakibatkan kelelahan bagi karyawan karena banyaknya beban kerja.

Gibson dalam Chandra, (2017) menjelaskan beberapa indikator yang mempengaruhi beban kerja, yaitu :

1. Tekanan waktu

Dalam suatu waktu, tekanan waktu bisa memberikan motivasi dan prestasi kerja karyawan, akan tetapi tekanan waktu juga dapat mengakibatkan beban kerja yang berlebihan yang mengakibatkan banyaknya kesalahan dalam bekerja dan juga berkurangnya kondisi kesehatan karyawan.

2. Jam kerja

Jam kerja adalah faktor yang menyebabkan stress kerja di lingkungan kerja yang dapat meningkatkan beban kerja, seperti sering lembur.

3. Kemenduaan peran

Kemenduaan peran dapat mempengaruhi beban kerja seorang karyawan karena hal ini dapat mempengaruhi persepsi seseorang terhadap kinerjanya.

4. Kebisingan

Lingkungan kerja yang bising atau berada di keramaian dapat mempengaruhi konsentrasi seorang karyawan yang akan mempengaruhi tercapainya suatu tugas sehingga akan meningkatkan beban kerja seseorang.

5. Banyaknya informasi masuk

Banyaknya informasi yang diterima oleh karyawan secara bersamaan dapat meningkatkan beban kerja. Semakin banyak informasi yang diterima oleh seorang karyawan yang masing-masing informasi memberikan akibat yang berbeda akan dapat mempengaruhi konsentrasi karyawan.

6. Temperatur

Tinggi atau rendahnya temperatur suatu ruangan akan mempengaruhi kondisi kesehatan karyawan. Hal ini terjadi apabila kondisi tersebut berlangsung dalam jangka waktu yang lama. 
7. Tindakan berulang

Gerakan berulang yang dilakukan oleh karyawan akan memberikan kebosanan yang akan menyebabkan berkurangnya perhatian dan konsentrasi karyawan terhadap pekerjaannya.

8. Tanggungjawab

Jenis tanggungjawab yang berbeda merupakan beban kerja bagi sejumlah karyawan, karena kemampuan karyawan untuk menerima dan melaksanakan tanggungjawab tersebut berbeda pula.

Berdasarkan uraian di atas mengenai konsep beban kerja, maka dapat penulis simpulkan bahwa beban kerja adalah suatu uraian tugas baik terlalu banyak atau terlalu sedikit pekerjaan yang harus dikerjakan dalam jangka waktu yang telah ditetapkan. Adapun indikator beban kerja yang digunakan dalam penelitian ini yaitu menurut Gibson dalam Chandra: (2017) adalah tekanan waktu, jam kerja, kemenduaan peran, kebisingan, banyaknya informasi masuk, temperatur, tindakan berulang dan tanggungjawab.

Banyak penelitian yang telah dilakukan para peneliti tentang pengaruh beban kerja terhadap kinerja seorang karyawan atau kinerja suatu organisasi. Adapun temuan penelitian yang mendukung teori tersebut diantaranya hasil penelitian Hannani, dkk (2016) yang berjudul Pengaruh Beban Kerja, Kepuasan dan Fasilitas terhadap Kinerja Perawat di Ruang Perawatan Mawar Lantai II RSU Wisata UTT Makassar. Berdasarkan penelitian yang dilakukan didapatkan hasil bahwa beban kerja berpengaruh positif dan signifikan terhadap kinerja Perawat di Ruang Perawatan Mawar Lantai II RSU UIT yaitu dengan nilai parameter standarized 0.325 dengan nilai signifikan 0.003., Widyastuti (2015) yang meneliti tentang Pengaruh Stres Kerja dan Beban Kerja Terhadap Kinerja SKPD Kabupaten Sintang Kalimantan Barat. Penelitian tersebut menunjukkan hasil bahwa beban kerja berpengaruh terhadap kinerja pegawai, Aprilia (2017) dengan judul penelitian Pengaruh Beban Kerja, Stres Kerja dan Motivasi Kerja terhadap Kinerja Perawat Rumah Sakit Islam Ibnu Sina Pekanbaru. Hasil penelitian tersebut menunjukkan bahwa beban kerja berpengaruh signifikan terhadap kinerja perawat Rumah Sakit Ibnu Sina Pekanbaru. Selain itu ada juga penelitian yang mendapatkan hasil penelitian beban kerja tidak memiliki pengaruh terhadap kinerja, seperti penelitian Iskandar (2017) dengan judul penelitian Pengaruh Karakteristik Individu, Beban Kerja Dan Lingkungan Kerja Terhadap Kinerja Pegawai Pada Karyawan Inspektorat Daerah Provinsi Sulawesi Tengah. Berdasarkan penelitian tersebut didapatkan hasil bahwa beban kerja berpengaruh negatif dan signifikan terhadap kinerja pegawai pada Inspektorat Daerah Provinsi Sulawesi Tengah, dan Riny Chandra dan Dody Adriansyah (2017) dengan judul penelitian Pengaruh Beban Kerja dan Stress Kerja terhadap Kinerja Karyawan pada PT. Mega Auto Central Finance Cabang di Langsa. Penelitian tersebut menunjukkan hasil bahwa beban kerja berpengaruh negatif terhadap kinerja. 


\section{Pengelolaan Keuangan Desa/Nagari}

Dalam Permendagri Republik Indonesia Nomor 20 Tahun 2018 tentang Pengelolaan Keuangan Desa, pengelolaan keuangan desa merupakan seluruh kegiatan yang mencakup perencanaan, pelaksanaan, penatausahaan, pelaporan, pertanggungjawaban dan pengawasan keuangan daerah yang dilakukan secara :

1. Transparan, adalah prinsip keterbukaan yang memungkinkan masyarakat supaya mendapatkan informasi sebanyaknya yang berkaitan dengan pengelolaan keuangan desa/APBDesa.

2. Akuntabel, adalah keharusan seseorang supaya bertanggungjawab dalam mengelola dan mengendalikan sumberdaya, pelaksanaan dan kebijakan yang dipercayakan untuk pencapaian tujuan yang telah ditentukan.

3. Partisipatif, merupakan dalam pengelolaan keuangan desa agar masyarakat untuk turut aktif dalam setiap proses pengelolaan keuangan desa.

4. Tertib dan disiplin anggaran, bahwa APBDesa harus di kelola tepat waktu dan tepat sasaran dan mempunyai bukti administrasi yang dapat dipertanggungjawabkan dan berpedoman kepada peraturan yang berlaku.

\section{Metode Penelitian}

Penelitian ini menggunakan metode kuantitatif yang merupakan analisisnya berupa data numerik atau angka yang diolah menggunakan metode statistik. Dalam penelitian ini peneliti membatasi populasi untuk dijadikan sampel yaitu hanya perangkat nagari yang terdiri dari 75 nagari di Kabupaten Tanah Datar. Sedangkan sampel penelitian ini berjumlah 248 responden yang ditentukan dengan rumus Slovin serta dilakukan dengan teknik pengambilan sampel Multi stage Random Sampling.

Dalam penelitian ini, data dikumpulkan menggunakan angket dan skala pengukuran yang digunakan yaitu skala likert dengan 4 pilihan jawaban (sangat setuju, setuju, kurang setuju dan tidak setuju). Selanjutnya data yang telah terkumpul dianalisis dengan teknik regresi linear berganda. Sebelum uji regresi dilakukan, maka terlebih dahulu dilakukan uji asumsi klasik. Sementara dalam memperoleh gambaran umum terkait dengan kedua variabel diperlukan juga frekuensi, mean dan TCR (Tingkat Capaian Responden).

\section{Hasil Penelitian dan Pembahasan}

\section{Hasil Penelitian}

Dalam bagian pendahuluan di atas, penelitian ini akan memberikan jawaban terkait dengan rumusan masalah apakah terdapat pengaruh beban kerja (terdiri dari delapan sub variabel yaitu tekanan waktu, jam kerja, kemenduaan peran, kebisingan, banyaknya informasi masuk, temperatur, tindakan berulang dan tanggungjawab secara simultan/bersama) terhadap kinerja perangkat nagari dalam pengelolaan keuangan nagari di Kabupaten Tanah Datar ? Untuk menjawab 
pertanyaan penelitian ini dapat dilihat data temuan penelitian pada Tabel 1 berikut.

Tabel 1. Pengaruh Beban Kerja terhadap Kinerja Perangkat Nagari dalam Pengelolaan Keuangan Nagari

\begin{tabular}{lrrrrr}
\multicolumn{6}{c}{ Model Summary $^{\mathbf{b}}$} \\
\hline Model & R & R Square & $\begin{array}{c}\text { Adjusted R } \\
\text { Square }\end{array}$ & $\begin{array}{c}\text { Std. Error of the } \\
\text { Estimate }\end{array}$ & Durbin-Watson \\
\hline 1 &, $272^{\mathrm{a}}$ &, 074 &, 043 &, 339 & 1,748 \\
\hline
\end{tabular}

a. Predictors: (Constant), Tanggungjawab, Kemenduaan Peran, Temperatur, Tekanan Waktu, Kebisingan, Banyaknya Informasi Masuk, Tindakan berulang, Jam Kerja

b. Dependent Variable: Rata-rata Pengelolaan Keuangan Nagari

Tabel 2. Hasil Uji Anova (F) Pengaruh Variabel Beban Kerja terhadap Kinerja Perangkat Nagari dalam Pengelolaan Keuangan Nagari

\begin{tabular}{rlrrrrr}
\hline \multicolumn{7}{c}{ ANOVA $^{\text {a }}$} \\
\hline Model & & Sum of Squares & df & Mean Square & F & Sig. \\
\hline \multirow{2}{*}{1} & Regression & 2,195 & 8 &, 274 & 2,383 &, $017^{\mathrm{b}}$ \\
& Residual & 27,516 & 239 &, 115 & & \\
& Total & 29,711 & 247 & & & \\
\hline
\end{tabular}

a. Dependent Variable: Rata-rata Pengelolaan Keuangan Nagari

b. Predictors: (Constant), Tanggungjawab, Kemenduaan Peran, Temperatur, Tekanan Waktu,

Kebisingan, Banyaknya Informasi Masuk, Tindakan Berulang, Jam Kerja

Berdasarkan Tabel 1 dapat dijelaskan bahwa nilai Adjusted $R$ Square yang diperoleh sebesar 0,043. Artinya, secara bersama-sama besarnya pengaruh variabel beban kerja terhadap kinerja perangkat nagari dalam pengelolaan keuangan nagari adalah sebesar 4,3\%. Sementara sisanya sebesar 95,7\% dipengaruhi oleh faktor lain yang tidak diteliti dalam penelitian ini. Dalam hal ini beban kerja berpengaruh secara signifikan terhadap kinerja perangkat nagari dalam pengelolaan keuangan nagari. Secara simultan nilai signifikan variabel lebih kecil dari 0.05, maka Ho di tolak dan Ha diterima. Selain itu, jika diperhatikan hasil uji Anova pada Tabel 2 di atas diperoleh angka signifikan sebesar $0,017^{\mathrm{a}}$. Artinya, kebenaran kesimpulan hasil hasil uji regresi ini dapat dipercaya sampai $100 \%$.

Selanjutnya, besaran pengaruh variabel beban kerja terhadap kinerja perangkat nagari dalam pengelolaan keuangan nagari secara parsial dapat dilihat pada Tabel 3 dibawah ini: 
Tabel 3. Pengaruh Sub Variabel Beban Kerja Secara Parsial terhadap Kinerja Perangkat Nagari dalam Pengelolaan Keuangan Nagari

\begin{tabular}{lccrl}
\hline \multicolumn{1}{c}{ Sub Variabel } & R & R Square & Adjusted R Square & \multicolumn{1}{c}{ Sig. } \\
\hline Tekanan waktu & $.208^{\mathrm{a}}$ & .043 & .039 & $.001^{\mathrm{b}}$ \\
\hline Jam kerja & $.180^{\mathrm{a}}$ & .032 & .028 & $.005^{\mathrm{b}}$ \\
\hline Kemenduaan peran & $.114^{\mathrm{a}}$ & .013 & .009 & $.073^{\mathrm{b}}$ \\
\hline Kebisingan & $.151^{\mathrm{a}}$ & .023 & .019 & $.018^{\mathrm{b}}$ \\
\hline $\begin{array}{l}\text { Banyaknya informasi } \\
\text { masuk }\end{array}$ & $.211^{\mathrm{a}}$ & .045 & .041 & $.001^{\mathrm{b}}$ \\
\hline Temperatur & $.071^{\mathrm{a}}$ & .005 & .001 & $.265^{\mathrm{b}}$ \\
\hline Tindakan berulang & $.067^{\mathrm{a}}$ & .004 & .000 & $.296^{\mathrm{b}}$ \\
\hline Tanggungjawab & $.187^{\mathrm{a}}$ & .035 & .031 & $.003^{\mathrm{b}}$ \\
\hline
\end{tabular}

Berdasarkan Tabel 3 di atas, nilai Adjusted $R$ Square sub variabel tekanan waktu sebesar 0,039. Yang berarti bahwa pengaruh beban kerja terhadap kinerja perangkat nagari dalam pengelolaan keuangan nagari adalah sebesar 3,9\%. Selanjutnya nilai Adjusted $R$ Square untuk sub-variabel jam kerja adalah sebesar 0,028 . Hal ini berarti bahwa pengaruh jam kerja terhadap kinerja perangkat nagari dalam pengelolaan keuangan nagari adalah sebesar 2,8\%. Sementara nilai Adjusted $R$ Square untuk sub-variabel kemenduaan peran adalah sebesar 0,009. Hal ini berarti bahwa pengaruh kemenduaan peran terhadap kinerja perangkat nagari dalam pengelolaan keuangan nagari adalah sebesar $0,9 \%$. Nilai Adjusted $R$ Square untuk sub-variabel kebisingan adalah sebesar 0,019. Hal ini berarti bahwa pengaruh kebisingan terhadap kinerja perangkat nagari dalam pengelolaan keuangan nagari adalah sebesar 1,9\%. Sedangkan nilai Adjusted $R$ Square untuk sub-variabel banyaknya informasi masuk adalah sebesar 0,041 . Hal ini berarti bahwa pengaruh banyaknya informasi masuk terhadap kinerja perangkat nagari dalam pengelolaan keuangan nagari adalah sebesar 4,1\%. Kemudian nilai Adjusted $R$ Square untuk sub-variabel temperatur adalah sebesar 0,001. Hal ini berarti bahwa pengaruh temperatur terhadap kinerja perangkat nagari dalam pengelolaan keuangan nagari adalah sebesar $0,1 \%$. Selain itu, nilai Adjusted $R$ Square untuk sub-variabel tindakan berulang adalah sebesar 0,000, Hal ini berarti bahwa pengaruh temperatur terhadap kinerja perangkat nagari dalam pengelolaan keuangan nagari adalah sebesar $0 \%$. Kemudian, hasil rumusan hipotesis penelitian menghasilkan Terdapat Pengaruh Beban Kerja terhadap Kinerja Perangkat Nagari dalam Pengelolaan Keuangan Nagari di Kabupaten Tanah Datar.

\section{Pembahasan}

Hasil penelitian tentang pengaruh beban kerja terhadap kinerja perangkat nagari dalam pengelolaan keuangan nagari di Kabupaten Tanah Datar telah membuktikan bahwa secara simultan terdapat pengaruh beban kerja terhadap kinerja perangkat nagari dalam pengelolaan keuangan nagari di Kabupaten Tanah Datar, akan tetapi secara sendiri-sendiri dari delapan sub variabel beban kerja, yaitu tekanan waktu, jam kerja, kemenduaan peran, banyaknya informasi masuk, tindakan berulang dan tanggungjawab, terdapat tiga sub variabel dari beban kerja 
yang tidak berpengaruh terhadap kinerja perangkat nagari dalam pengelolaan keuangan nagari, yaitu kemenduaan peran, temperatur dan tindakan berulang. Secara simultan pengaruh beban kerja terhadap perangkat nagari dalam pengelolaan keuangan nagari di Kabupaten Tanah Datar menghasilkan angka signifikansi 0,017 dan nilai Adjust $R$ Square sebesar 0,043 sehingga dapat dikatakan bahwa kontribusinya adalah sebesar $4,3 \%$ dan nilai $\mathrm{R}$ sebesar $0,074^{\mathrm{a}}$ yang berarti bahwa kekuatan variabel beban kerja perangkat nagari terhadap pengelolaan keuangan nagari di Kabupaten Tanah Datar sebesar 7,4\%. Dengan demikian, dapat disimpulkan bahwa secara simultan beban kerja perangkat nagari memiliki pengaruh secara signifikan terhadap pengelolaan keuangan nagari di Kabupaten Tanah Datar, akan tetapi secara parsial yaitu sub variabel kemenduaan peran, temperatur dan tindakan berulang tidak berpengaruh yang signifikan terhadap kinerja perangkat nagari dalam pengelolaan keuangan nagari di Kabupaten Tanah Datar.

Selanjutnya, hasil uji secara sendiri-sendiri pengaruh sub variabel tekanan waktu (X1), jam kerja (X2), kemenduaan peran (X3), kebisingan (X4), banyaknya informasi masuk (X5), temperatur (X6), tindakan berulang (X7), dan tanggungjawab (X8) terhadap pengelolaan keuangan nagari menghasilkan nilai Adjust $R$ Square untuk tekanan waktu sebesar 0,001, untuk jam kerja, 0,005, untuk kemenduaan peran, 0,073, untuk kebisingan, 0,018, untuk banyaknya informasi masuk, 0,001, untuk temperatur 0,265, untuk tindakan berulang 0,296, dan tanggungjawab,003. Oleh karenanya dapat dikatakan bahwa kontribusi tekanan waktu terhadap pengelolaan keuangan nagari sebesar 3,9\%, jam kerja sebesar $2,8 \%$, kemenduaan peran sebesar $0,9 \%$, kebisingan sebesar $1,9 \%$, banyaknya informasi masuk sebesar $4,1 \%$, temperatur sebesar $0,1 \%$, tindakan berulang sebesar $0 \%$ tanggungjawab sebesar $3,1 \%$.

Dengan penjelasan di atas dapat dipahami bahwa hasil penelitian ini dapat membuktikan dan memperkuat teori-teori dan temuan penelitian yang sudah ada, seperti yang dikemukakan oleh Luthan (dalam Kasmir, 2016:194) yang berpendapat bahwa beban kerja yang diemban oleh seorang akan berpengaruh terhadap kinerjanya. Selain itu Lisnayetti dan Hasanbari (2006), terdapat kaitan antara beban kerja terhadap kinerja dimana beban kerja yang tinggi akan mengakibatkan kurangnya kinerja karyawan.

Hasil penelitian ini juga mendukung dan berkaitan dengan penelitian sebelumnya yang dilakukan oleh Hannani,dkk (2016), Widyastuti (2015), Aprilia (2017) yang mendapatkan hasil penelitian bahwa variabel beban kerja berpengaruh secara signifikan terhadap kinerja pegawai atau karyawan dalam melaksanakan pekerjaan.

\section{Penutup}

Berdasarkan hasil penelitian dan pembahasan di atas, dapat disimpulkan bahwa :

1. Variabel Beban Kerja (X) secara simultan memiliki pengaruh terhadap Variabel Pengelolaan Keuangan Nagari (Y) di Kabupaten Tanah Datar.

2. Secara parsial sub variabel beban kerja memiliki pengaruh terhadap kinerja perangkat nagari dalam pengelolaan keuangan nagari, yaitu sub variabel 
tekanan waktu, sub variabel jam kerja, sub variabel kemenduaan peran, sub variabel kebisingan, dan sub variabel tanggungjawab. Akan tetapi sub variabel dari beban kerja juga ada yang tidak memiliki pengaruh terhadap kinerja, yaitu sub variabel banyaknya informasi masuk, sub variabel kebisingan dan sub variabel tindakan berulang.

Berdasarkan hasil penelitian dan kesimpulan yang telah diuraikan di atas, adapun saran-saran yang dapat peneliti kemukakan adalah sebagai berikut:

1. Hasil penelitian ini menunjukkan bahwa sub variabel tekanan waktu, jam kerja, kebisingan, banyaknya informasi masuk dan tanggungjawab mempunyai pengaruh yang signifikan terhadap kinerja perangkat nagari dalam pengelolaan keuangan nagari di Kabupaten Tanah Datar. Dan secara keseluruhan beban kerja memiliki pengaruh yang signifikan terhadap kinerja perangkat nagari dalam pengelolaan keuangan nagari di Kabupaten Tanah Datar dengan nilai kontribusi sebesar 4,3\%. Dengan demikian disarankan kepada setiap perangkat nagari agar lebih memperhatikan beban kerja perangkat nagari khususnya pada sub variabel tekanan waktu, jam kerja, kebisingan, banyaknya informasi masuk dan tanggungjawab. Apabila perangkat nagari bekerja dalam tekanan waktu seperti deadline tugas yang harus dikerjakan dan jam kerja yang tidak cukup yang biasanya sering terjadi pada akhir tahun, maka hal ini akan menyebabkan turunnya kualitas perangkat nagari dalam mengerjakan tugasnya yang tentunya akan berdampak terhadap kinerja mereka. Karena semakin tinggi beban kerja mereka maka akan semakin rendah kinerjanya.

2. Peneliti menyadari bahwa hasil penelitian ini masih memiliki kelemahan tertentu, maka dari itu diharapkan kepada peneliti selanjutnya untuk lebih menyempurnakan penelitian ini dengan melakukan penelitian yang lebih mendalam sekaligus menyertakan berbagai variabel lain yang memiliki pengaruh terhadap pengelolaan keuangan nagari di Kabupaten Tanah Datar.

\section{DAFTAR KEPUSTAKAAN}

\section{Buku dan Jurnal}

Aprilia, Friska. 2017. Pengaruh Beban Kerja, Stres Kerja dan Motivasi Kerja terhadap Kinerja Perawat Rumah Sakit Ibnu Sina Pekanbaru. JOM Fekon (Vol. 4,No. 1, Februari 2017)

Chandra, Riny dan Dody Adriansyah. 2017. Pengaruh Beban Kerja dan Stres Kerja terhadap Kinerja Karyawan pada PT. Mega Auto Central Finance Cabang di Langsa. Jurnal Manajemen dan Keuangan (Vol 6, No 1, Mei 2017)

Fahmi, Irham. 2016. Manajemen Sumber Daya Manusia Teori dan Aplikasi. Bandung : Alfabeta

Hannani,dkk. 2016. Pengaruh Beban Kerja, Kepuasan Kerja dan Fasilitas terhadap Kinerja Perawat di Ruang Perawatan Mawar Lantai II RSU 
Wisata UIT Makassar. Jurnal Mirai Management. (Volume 1 Nomor 2, Oktober 2016)

Iskandar, Sentot. 2012. Pengaruh Beban Kerja, Motivasi Kerja dan Kepuasan Kerja terhadap Kinerja Pegawai Bank BJB Cabang Padalarang. Jurnal Ekonomi, Bisnis \& Entrepreneurship. (Vol. 6, No. 1, April 2012)

Kasmir. 2016. Manajemen Sumber Daya Manusia (Teori dan Praktik). Jakarta : PT Raja Grafindo Persada

Lisnayetti., \& Hasanbari, M. (2006). Beban Kerja dan Kinerja Dosen Poltekes Padang : Working Paper Series.

Mangkuprawira. S. 2003. Manajemen Sumber Daya Manusia Strategik. Jakarta : CV. Ghalia Indonesia

Munandar, Ashar Sunyoto. 2001. Psikologi Industri dan Organisasi. Jakarta : Universitas Indonesia Press

Syamsir. (2017). Model Pembinaan Kapasitas Aparatur Pemerintah Nagari dalam Pengelolaan Keuangan Nagari di Kabupaten Tanah Datar Provinsi Sumatera Barat. Laporan Penelitian. Padang : Universitas Negeri Padang.

Syamsir dan Baiyulis. 2018. Pengaruh Kepuasan Kerja Terhadap Kinerja Perangkat Nagari dalam Pengelolaan Keuangan Nagari di Kecamatan Sungai Tarab dan Salimpaung. Journal of Education on Social Sciense. (Vol.2, No.2, Oktober 2018)

Syamsir dan Nur Putri Jayanti. 2018. Pengaruh Lingkungan Kerja Terhadap Kinerja Perangkat Nagari Dalam Pengelolaan Keuangan Nagari di Kabupaten Tanah Datar. Journal of Education on Social Sciense. (Vol.2, No.1, April 2018)

Syamsir dan Rahmi Suci. 2018. Pengaruh Kompensasi Terhadap Kinerja Perangkat Nagari Dalam Pengelolaan Keuangan Nagari Di Kecamatan Salimpaung. Journal of Education on Social Sciense. (Vol.2, No.1, April 2018)

Widyastuti, Niken. 2015. Pengaruh Stres Kerja dan Beban Kerja terhadap Kinerja SKPD Kabupaten Sintang Kalimantan Barat. Jurnal Maksipreneur. (Vol.IV, No.2, Juni 2015)

Wirawan. 2009. Evaluasi Kinerja Sumber Daya Manusia. Jakarta : Salemba Empat.

\section{Peraturan Perundang-undangan}

Peraturan Pemerintah Nomor 47 Tahun 2015 tentang Peraturan Pelaksanaan Undang-Undang Nomor 6 Tahun 2014 tentang Desa

Peraturan Pemerintah Nomor 58 Tahun 2005 tentang Pengelolaan Keuangan Daerah

Peraturan Menteri Dalam Negeri Republik Indonesia Nomor 20 Tahun 2018 Tentang Pengelolaan Keuangan Desa 
Peraturan Bupati Tanah Datar Nomor 7 Tahun 2016 tentang Perubahan Atas Peraturan Bupati Nomor 11 Tahun 2015 tentang Pedoman Pengelolaan Keuangan Nagari

\section{Sumber Berita}

Redaksi Sumbar (2017). Akibat tiga nagari bermasalah pemkab Tanah Datar terancam tidak dapat cairkan dana ADD tahap II. http://redaksisumbar.com/akibat-tiga-nagari-bermasalah-pemkab-tanahdatar-terancam-tidak-dapat-cairkan-dana-add-tahap-ii/ 